\title{
Kajian Analisis Struktur Jembatan Gantung Pejalan Kaki Asimetris Ganda
}

\section{ALTIE SANTIKA ARIFIN ${ }^{1}$, BERNARDINUS HERBUDIMAN ${ }^{1}$, GATOT SUKMARA ${ }^{2}$}

\author{
1. Jurusan Teknik Sipil, Institut Teknologi Nasional, Bandung
}

2. Puslitbang Jalan dan Jembatan, Kementerian Pekerjaan Umum dan

Perumahan Rakyat

Email: altiearifin2@gmail.com

\begin{abstract}
ABSTRAK
Keberadaan jembatan sangat membantu perkembangan ekonomi penduduk, karena terhubungnya satu wilayah dengan wilayah lainnya. JUDESA (Jembatan Untuk Pedesaan Asimetris) adalah jembatan gantung yang dikembangkan oleh Puslitbang Jalan Jembatan, didesain tipikal dapat mengakomodasi kebutuhan panjang jembatan dengan bentang $30 \mathrm{~m}$ hingga $120 \mathrm{~m}$. Terdapat dua tipe JUDESA yaitu asimetris tunggal dan asimetris ganda. Penelitian ini mengkaji JUDESA asimetris ganda dengan bentang 120 $m$. Perubahan geometrik pada jembatan gantung memberi efek yang signifikan dalam aspek kekuatan struktur. Pada penelitian ini diajukan alternatif konfigurasi batang penggantung dengan menggunakan dimensi dan mutu yang sama. Konfigurasi 1 menempatkan batang penggantung dengan jarak $2 m$ sepanjang setengah bentang dan konfigurasi 2 menempatkan batang penggantung sepanjang bentang dengan jarak pisah 4m. Pemodelan dan perencanaan jembatan gantung menggunakan SAP2000 ver.20. Dari hasil pemodelan dan pengecekkan, didapatkan konfigurasi model 2 menunjukan perilaku struktur yang lebih baik dengan beberapa parameter yang dijadikan acuan.
\end{abstract}

Kata Kunci: jembatan gantung, asimetris ganda, konfigurasi batang penggantung

\section{ABSTRACT}

The existence of the bridge is very helpful economic development of the population, because the connected one region with other areas. JUDESA (Jembatan Untuk Pedesaan Asimetris) is a suspention bridge that developed by Puslitbang Jalan Jembatan, designed to accommodate a tyipical bridge with span $30 \mathrm{~m}$ to $120 \mathrm{~m}$. In this study will analysis double asymmetrical bridge with span $120 \mathrm{~m}$. Changes of geometric have a significant effect on the suspention bridge. Type 1 have the configuration that hanger placed in every $2 m$ on the half-sapan. Type 2 have the configuration that hanger places ini every $4 \mathrm{~m}$ along the span. This suspention bridge modeling by used SAP2000 ver. 20. From the modeling and analysis, type 2 shows that configuration give the better structure performance with the parameter that used.

Keywords: suspention bridge, double asymmetric, configuration of hanger 


\section{PENDAHULUAN}

\subsection{Latar Belakang}

Kondisi geografis Indonesia yang merupakan daratan yang terpisah oleh laut, sungai ataupun lembah mendorong ekonommi di Indonesia tidak merata. Nawacita adalah program pemerintah yang salah satu programnya adalah membangun Indonesia dari pinggiran dengan memperkuat daerah-daerah dan desa dalam kerangka negara kesatuan. Hal ini mendorong pembangunan infrastruktur yang memadai di daerah-daerah dan desa-desa salah satunya infrastruktur penghubung yaitu jembatan. Jembatan gantung adalah infrastruktur yang banyak dibangun karena dapat mendukung kegiatan harian dan perekonomian warga.

Pada jurnal Jembatan Gantung Asimetris Untuk Pedesaan menjelaskan bahwa Puslitbang Jalan dan jembatan telah menyusun konsep JUDESA (Jembatan Untuk Pedesaan) dan melaksanakan penerapan JUDESA dengan bentang $42 \mathrm{~m}$ di Desa Cihawuk, Pangalengan, Kabupaten Bandung. Setelah dilakukan evaluasi terhadap jembatan tersebut maka disusun kembali JUDESA untuk tipe bentang lainnya, sehingga dapat mengakomodasi bentang 30 hingga 120 $m$ dengan beberapa tipe struktur yang dimodifikasi seperti terlihat pada Gambar 1 (Sukmara, G. \& Nugraha, W., 2016).

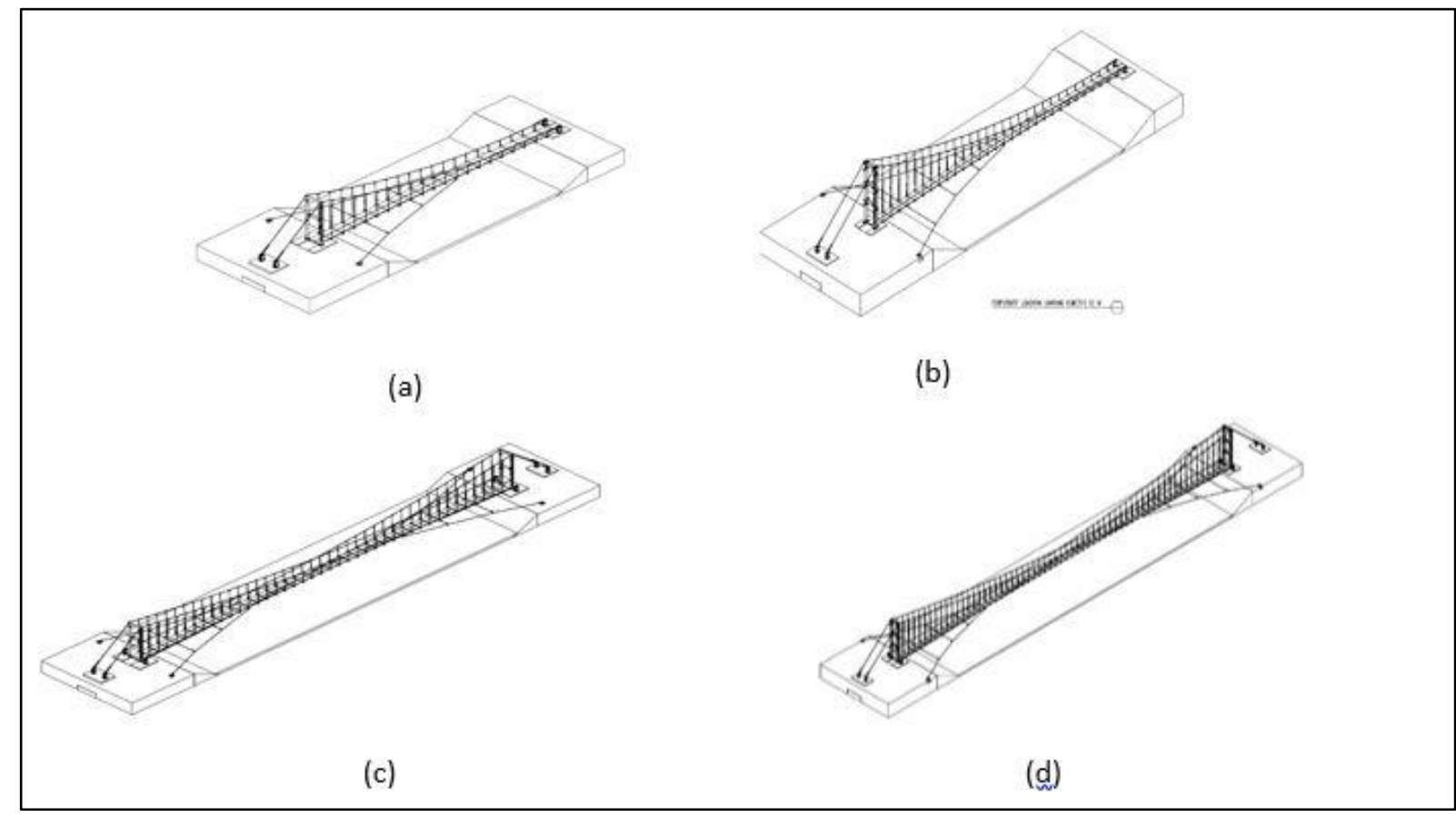

Gambar 1 (a) JUDESA tipe Asimetris I (Bentang $30 \mathrm{~m} \mathrm{~s} / \mathrm{d} 40 \mathrm{~m}$ ); (b) JUDESA tipe Asimetris II (Bentang $40 \mathrm{~m} \mathrm{~s} / \mathrm{d} 60 \mathrm{~m}$ ); (c) JUDESA tipe Double Asimetris I (Bentang $60 \mathrm{~m}$ s/d $80 \mathrm{~m}$ ); (d) JUDESA tipe Double Asimetris II (Bentang $80 \mathrm{~m} \mathrm{s/d} 120 \mathrm{~m}$ )

(Sumber: Sukmara, G. \& Nugraha, W., 2016)

Berdasarkan hasil penelitian tersebut akan dilakukan studi evaluasi lebih lanjut mengenai jembatan gantung asimetris ganda dengan bentang 120 meter dan mengajukan alternatif konfigurasi batang penggantung. Hasil dari penelitian ini diharapkan dapat memberikan alternative konfigurasi batang penggantung yang memiliki kinerja struktur lebih baik. 


\section{TINJAUAN PUSTAKA}

\subsection{Umum}

Berdasarkan UU 38 Tahun 2004 bahwa jalan dan jembatan sebagai bagian dari sistem transportasi nasional mempunyai peranan penting terutama dalam mendukung perkembangan ekonomi, sosial budaya, serta lingkungan melalui pendekatan pengembangan wilayah agar tercapai keseimbangan dan pemerataan pembangunan antar daerah. Jembatan secara umum adalah suatu konstruksi yang berfungsi untuk menghubungkan dua bagian jalan yang terputus oleh adanya rintangan-rintangan.

Jembatan gantung adalah jembatan yang pelat lantainya digantung pada kabel menggunakan batang-batang penggantung vertikal. Sistem ini menyalurkan beban yang diterima oleh pelat lantai menjadi tegangan pada kabel utama sehingga ujung-ujung kabel utama ini harus diangkur pada tanah keras. Jembatan gantung memiliki keuntungan karena memiliki bentang yang cukup panjang dan pengerjaan konstruksinya yang cukup mudah. Jembatan ini sangat cocok dikembangkan untuk suatu wilayah dengan kondisi geografis seperti Indonesia. (Dewobroto, W., 2005).

Kriteria perencanaan yang perlu dipertimbangkan untuk memastikan bahwa jembatan pejalan kaki aman dan sesuai untuk pengguna adalah kekuatan, lendutan, dan beban dinamik (Surat Edaran Menteri Pekerjaan Umum, 2010).

Pengguna jembatan harus diidentifikasi secara jelas karena akan menentukan lebar lantai jembatan yang diperlukan dan beban hidup pada jembatan yang akhirnya akan menentukan biaya konstruksi. Gambar 2 menunjukkan lebar yang dianjurkan untuk jalan masuk dan lintasan untuk tipe-tipe yang berbeda dari berbagai tingkatan lalu lintas.

Dua lebar standar yang dianjurkan pada pedoman ini adalah:

1. Lebar jembatan $1 \mathrm{~m}$ sampai dengan 1,4 $\mathrm{m}$ untuk pejalan kaki dua arah (jembatan pejalan kaki kelas II).

2. Lebar jembatan $1,4 \mathrm{~m}$ sampai dengan $1,8 \mathrm{~m}$ untuk tiga pejalan kaki yang beriringan (jembatan pejalan kaki kelas I).

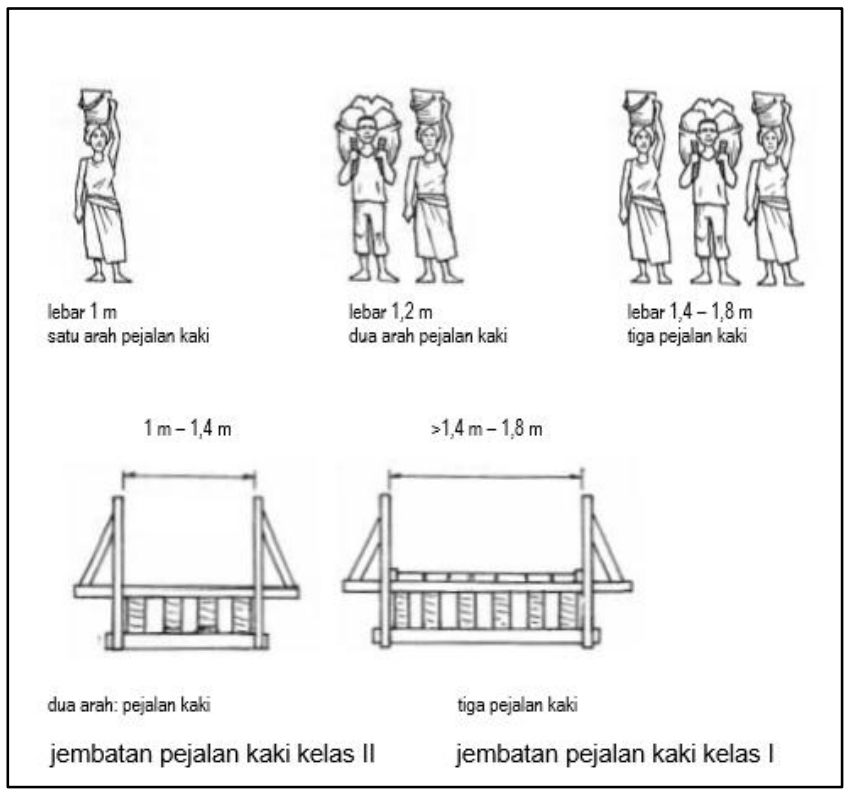

Gambar 2. Lebar jembatan yang dianjurkan sesuai dengan tingkatan lalu lintas (Sumber: Surat Edaran Menteri Pekerjaan Umum No.02/SE/M/2010) 


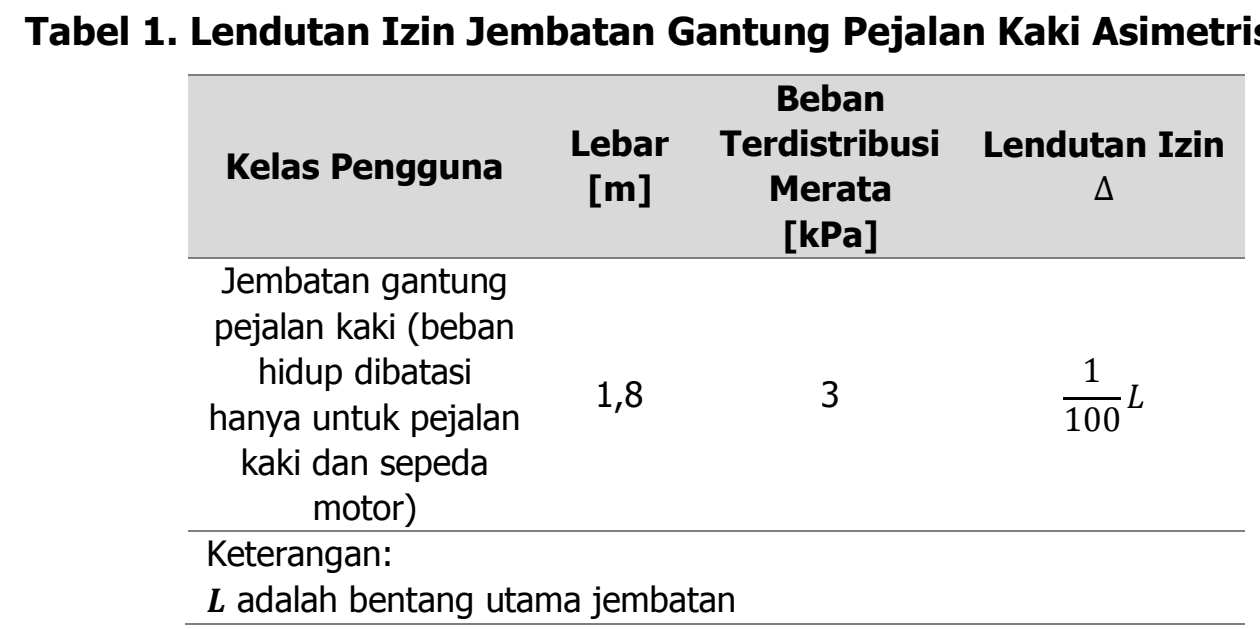

\subsection{Sistem Kabel}

Beberapa hal penting yang harus diperhatikan saat menganalisis konstruksi jembatan dengan sistem suspensi yaitu konstruksi dan perilaku kabel, geometri kabel dan perilaku deformasi sistem kabel. Kabel pada struktur jembatan merupakan elemen dasar berfungsi sebagai pendukung utama. Kabel merupakan bahan atau material utama dalam struktur jembatan suspension. Karakteristik kabel kaitannya dengan struktur jembatan suspension antara lain: (Supriyadi dan Muntohar, 2007).

a. Mempunyai penampang yang seragam/homogen pada seluruh bentang.

b. Tidak dapat menahan momen dan gaya desak.

c. Gaya-gaya dalam yang bekerja selalu merupakan gaya tarik aksial.

d. Bentuk kabel tergantung pada beban terbagi merata, maka wujudnya akan merupakan lengkung parabola.

e. Pada jembatan gantung kabel menderita beberapa beban titik sepanjang beban mendatar. Pada jembatan yang ditinjau kabel utama yan digunakan adalah IWRC. IWRC adalah jenis kabel yang mempunyai inti atau core baja yang berupa kumpulan strand yang dipilin seperti pada Gambar 3. Jumlah strand yang digunakan pada jenis kabel ini sangat beragam akan tetapi pada analisis yang akan dilakukan kali ini jenis kabel IWRC yang digunakan hanya IWRC $6 \times 36$.

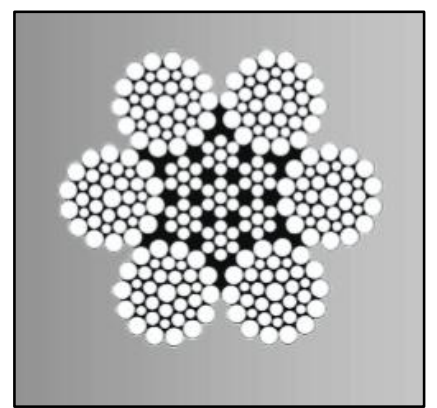

Gambar 3 Penampang kabel jenis IWRC 6×36

(Sumber: Steel Wire Rope, Ltd., 2018)

\subsection{Analisis Jembatan Gantung Pejalan kaki Asimetris Ganda}

Pengecekkan modul lantai dilakukan dengan menganalisis nilai momen dan gaya gesermaksimum untuk selanjutnya dibandingkan dengan kapasitas penampang yang ada menggunakan Persamaan 1 sebagai berikut: 


$$
f=\frac{f_{b}}{f_{b}^{\prime}}<1(O K)
$$

halmana:

$f \quad=$ rasio perbandingan tegangan aktual dengan tegangan izin,

$f_{b} \quad=$ tegangan aktual yang terjadi pada modul lantai $\left[\mathrm{kN} / \mathrm{m}^{2}\right]$,

$f_{b}^{\prime} \quad=$ tegangan izin dari modul lantai $\left[\mathrm{kN} / \mathrm{m}^{2}\right]$.

Selain pada modul lantai analisis elemen struktur dilakukan pada gelagar melintang dengan membandingkan nilai maksimal momen dan gaya geser yang terjadi seperti pada Persamaan 1. Selain analisis momen dan gaya geser pada gelagar melintang dilakukan analisis terhadap lendutan dengan menggunakan Persamaan 2 sebagai berikut:

$$
\Delta=\frac{5 * M * l^{2}}{48 * E * I_{x}}
$$

halmana:

$\Delta=$ lendutan yang terjadi pada gelagar melintang [mm],

$M=$ momen yang terjadi pada gelagar melintang [kNm],

$l$ = panjang gelagar melintang secara keseluruhan [m],

$E=$ modulus elastisitan gelagar melintang [MPa],

$I_{x}=$ momen inersia sumbu $x$ pada gelagar melintang $\left[\mathrm{m}^{4}\right]$.

Selanjutnya gaya tegangan kabel utama dihitung dengan Persamaan $\mathbf{3}$ sebagai berikut:

$$
\sigma=\frac{\text { Gaya aksial yang terjadi }}{\text { Luas penampang }}
$$

halmana:

$\sigma=$ gaya tegangan kabel utama [kN].

Selanjutnya gaya aksial pilon dengan menggunakan Persamaan 4 sebagai berikut:

$$
f=\frac{P_{u}}{\phi P_{n}}
$$

halmana:

$f \quad=$ rasio perbandingan tegangan aktual dengan tegangan izin,

$P_{u} \quad=$ tegangan aksial yang terjadi pada pilon [kN],

$\phi P_{n} \quad=$ tegangan aksial izin dari pilon [kN].

Pada pemodelan yang dilakukan pada penelitian kali ini beban-beban dimodelkan dengan beban merata yang ditempatkan pada gelagar melintang. Perhitungan beban untuk dimodelkan pada gelagar melintang dapat dihitung dengan Persamaan 5 sampai Persamaan 7 sebagai berikut:

$$
Q_{D}=\gamma * t * p
$$

halmana:

$Q_{D} \quad=$ beban mati, berasal dari berat sendiri $[\mathrm{kN} / \mathrm{m}]$,

$\gamma \quad=$ berat isi bahan $\left[\mathrm{kN} / \mathrm{m}^{3}\right]$,

$t \quad=$ tebal pelat jembatan $[\mathrm{m}]$,

$p \quad=$ panjang tributary area yang dihitung $[\mathrm{m}]$. 


$$
Q_{L}=L L * l
$$

halmana:

$Q_{L} \quad=$ beban hidup $[\mathrm{kN} / \mathrm{m}]$,

$L L \quad=$ beban hidup yang direncanakan $\left[\mathrm{kN} / \mathrm{m}^{2}\right]$,

$l \quad=$ lebar pelat jembatan $[\mathrm{m}]$.

$$
Q_{U}=Q_{D}+Q_{L}
$$

halmana:

$Q_{U} \quad=$ beban seluruhnya $[\mathrm{kN} / \mathrm{m}]$,

$Q_{D} \quad=$ beban mati, berasal dari berat sendiri $[\mathrm{kN} / \mathrm{m}]$,

$Q_{L} \quad=$ beban hidup $[\mathrm{kN} / \mathrm{m}]$.

\section{METODE PENELITIAN}

Pada penelitian ini dimulai dengan studi pustaka mengenai jembatan gantung pejalan kaki asimetris ganda, setelah studi pustaka dilakukan penulis mengumpulkan data-data yang diperlukan. Setelan data mutu dan dimensi didapatkan dilanjutkan dengan tahapan memodelkan struktur jembatan dengan menggunakan software SAP2000. Penulis memodelkan 2 model struktur jembatan asimetris ganda dengan konfigurasi kabel yang berbeda. Langkah selanjutnya adalah pengecekan elemen struktur untuk mengetahui kekuatan dan keamanan struktur. Bersamaan dengan pengecekkan elemen struktur pengecekkan dilakukan pada lendutan maksimal yang terjadi pada jembatan untuk mengetahui kekuatan struktur seperti terlitah pada Gambar 4.

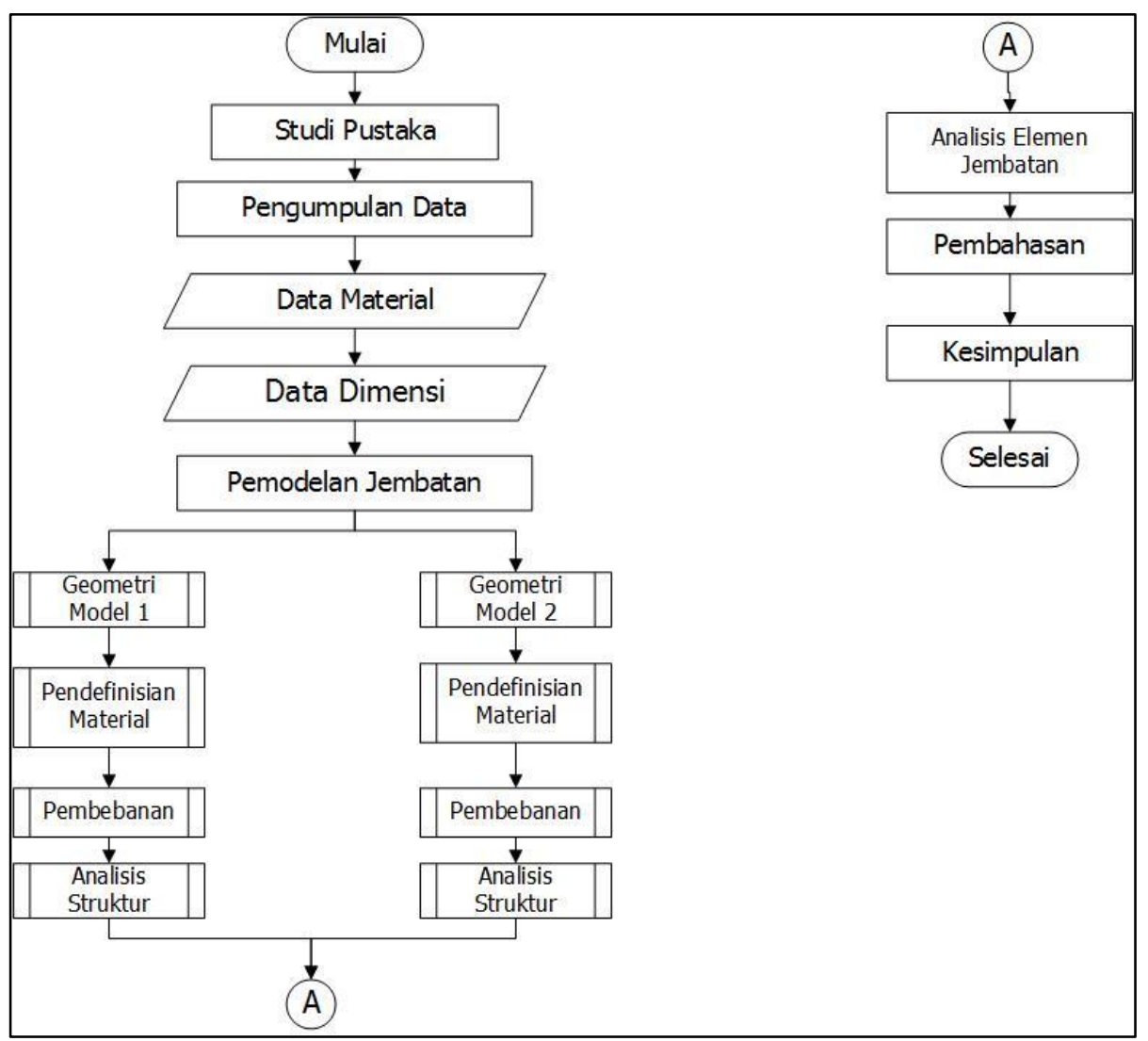

Gambar 4. Bagan alir penelitian 


\section{PEMODELAN STRUKTUR}

\subsection{Sistem Struktur}

Dimensi model jembatan yang akan dianalisis ditampilkan pada Tabel $\mathbf{2}$ dan gambar model jembatan ditunjukkan pada Gambar 5 dan Gambar 6.

Tabel 2. Data Dimensi Elemen Jembatan

\begin{tabular}{ccc} 
No. & Nama Komponen & Dimensi \\
\hline 1 & Sistem Panel Lantai & $2 \mathrm{~m} \times 1,8 \mathrm{~m}$ \\
\hline 2 & Hollow Memanjang & $\mathrm{H} 100.50 .2$ \\
\hline 3 & Gelagar Melintang & $\mathrm{C} 65 \times 42 \times 5,5 \times 6$ \\
\hline 4 & Kabel Utama & $\varnothing 50$ \\
\hline 5 & Kabel Hanger & $\varnothing 22$ \\
\hline 6 & Pilon & $\varnothing 10^{\prime \prime} \mathrm{t}=9,3 \mathrm{~mm}$
\end{tabular}

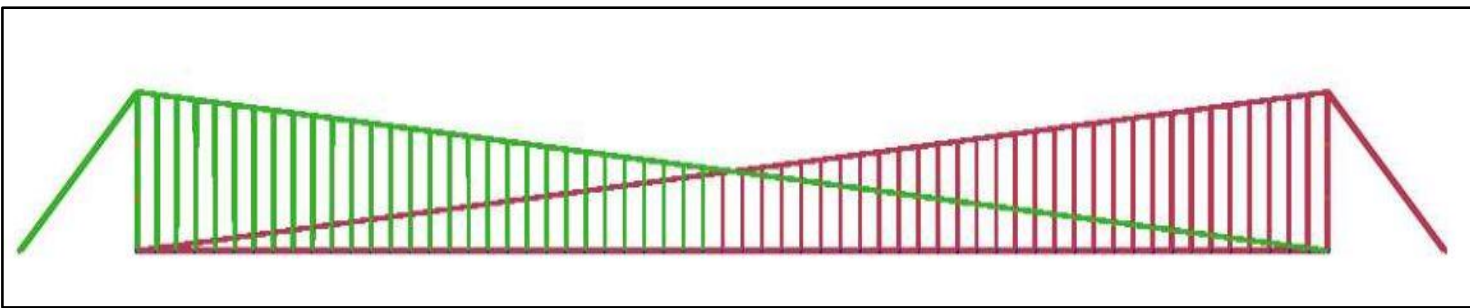

Gambar 5. Model 1 JUDESA asimetris ganda

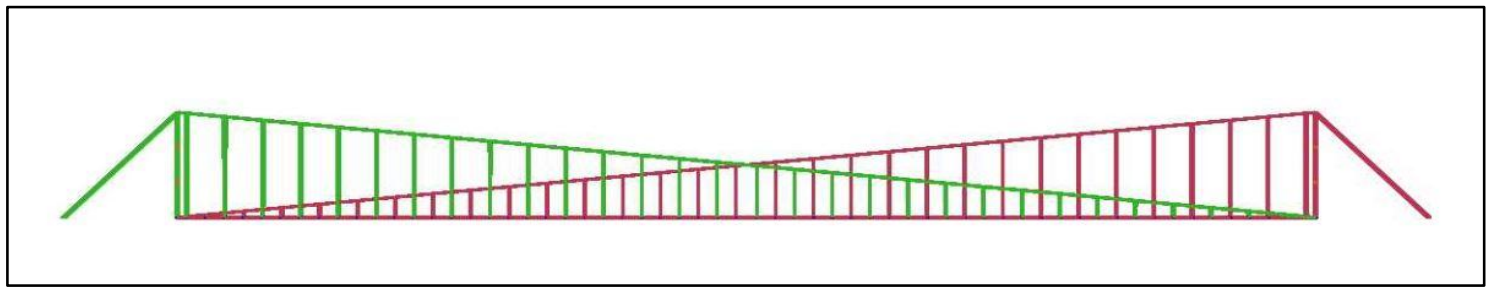

Gambar 6. Model 2 JUDESA asimetris ganda

Pemodelan pembebanan yang dilakukan dapat dilihat pada Gambar 7.

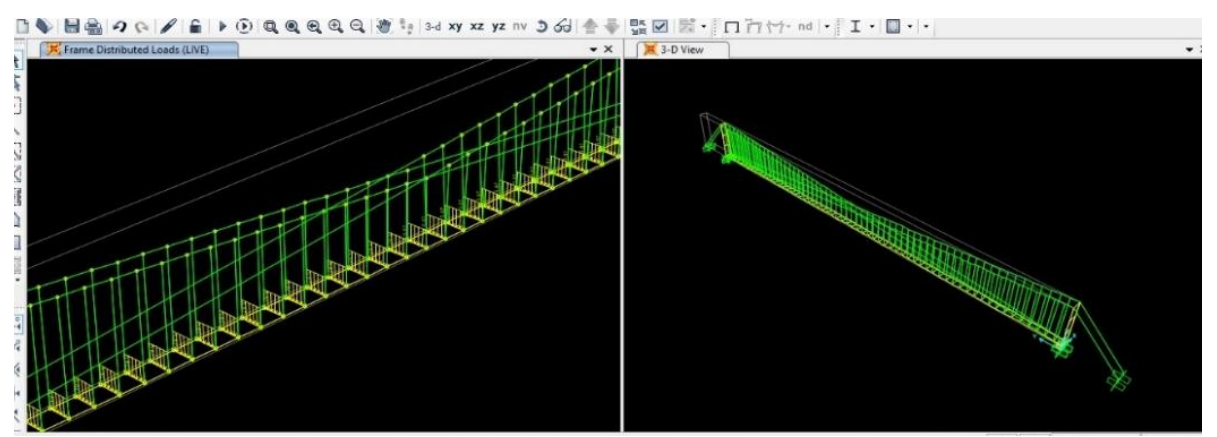

Gambar 7. Pemodelan beban 


\section{ANALISIS STRUKTUR DAN PEMBAHASAN}

\subsection{Analisis Struktur}

Analisis dilakukan sebanyak dua kali dengan konfigurasi batang penggantung yang berbeda. Hasil analisis berupa nilai defleksi, tegangan kabel backstay, dan momen maksimum gelagar seperti contoh salah satu hasil analisis yang ditunjukkan pada Gambar 8 hingga Gambar 14.

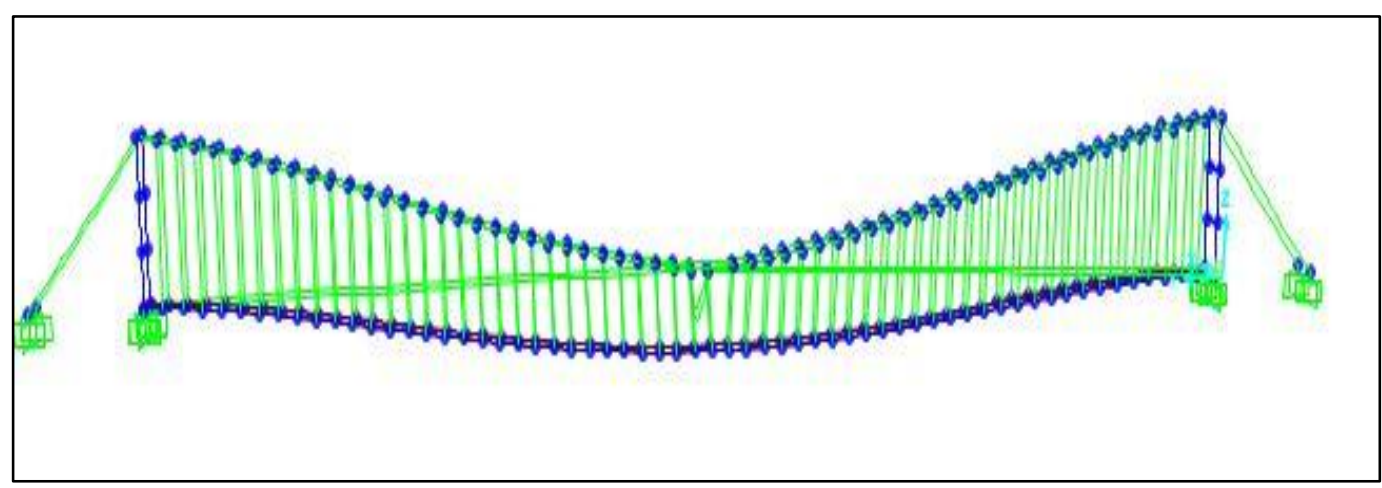

Gambar 8. Tampak samping deform shape akibat kombinasi DL+LL

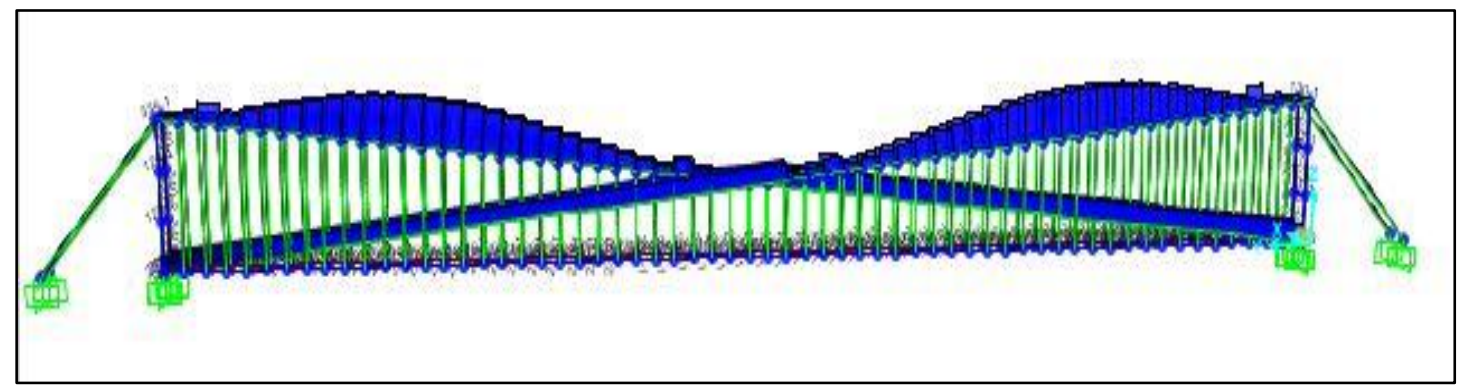

Gambar 9. Diagram gaya aksial

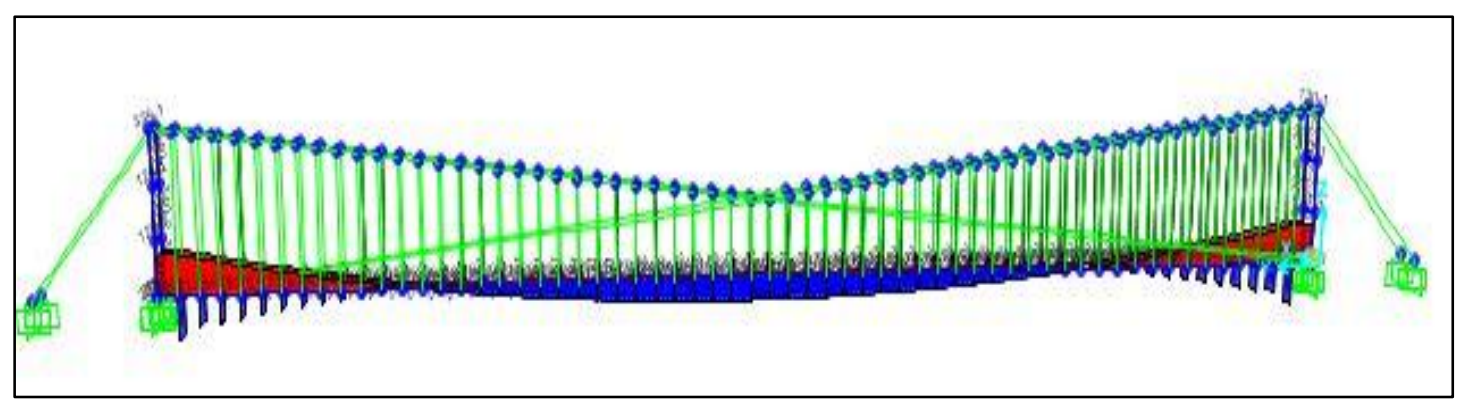

Gambar 10. Diagram gaya momen

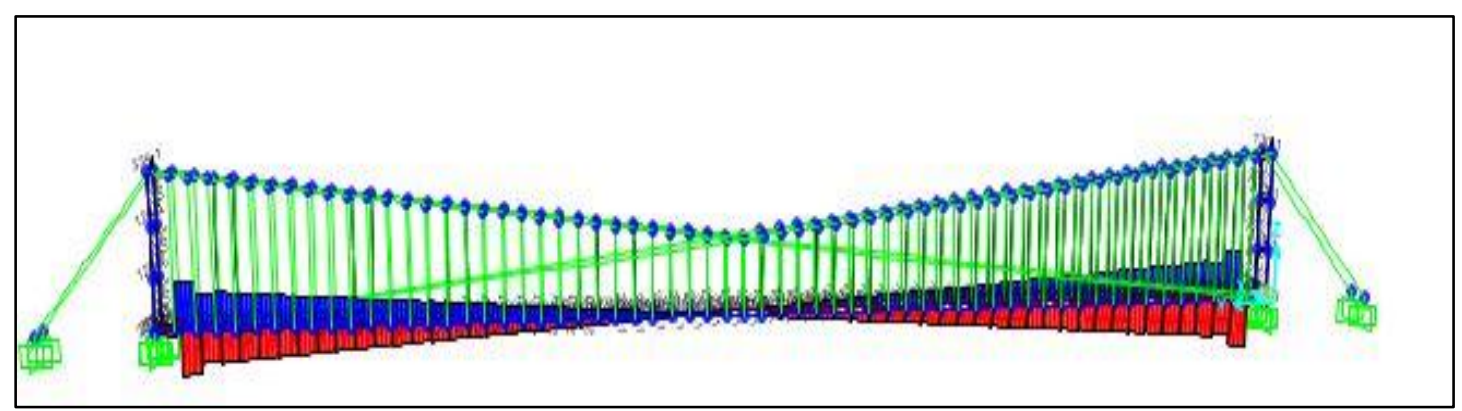

Gambar 11. Diagram gaya geser 


\subsection{Pembahasan Hasil Analisis Struktur}

Hasil dari seluruh analisis struktur jembatan ditabelkan dan dibandingkan antara Model 1 dan Model 2 dapat dilihat pada Tabel 3.

Tabel 3. Perbandingan Nilai Analisis Struktur Model 1 Dan Model 2

\begin{tabular}{ccc}
\hline Keterangan & Model 1 & Model 2 \\
\hline Gaya Kabel Utama [kN] & 1681.37 & 1001.75 \\
\hline Aksial Pilon [kN] & 1284.152 & 549.870 \\
\hline Momen pada Gelagar Memanjang $[\mathrm{kNm}]$ & 2.21297 & 1.78956 \\
\hline Geser pada Gelagar Memanjang $[\mathrm{kNm}]$ & 1.04471 & 0.49862 \\
\hline Lendutan $[\mathrm{m}]$ & 1.174 & 0.541 \\
\hline
\end{tabular}

Hasil dari analisis yang dilakukan pada Model 1 dan Model 2 ditemukan nilai yang memiliki selisih yang besar adalah nilai pada momen gelagar memanjang, perbandingan nilai momen pada kondisi layan dapat dilihat pada Gambar 12.

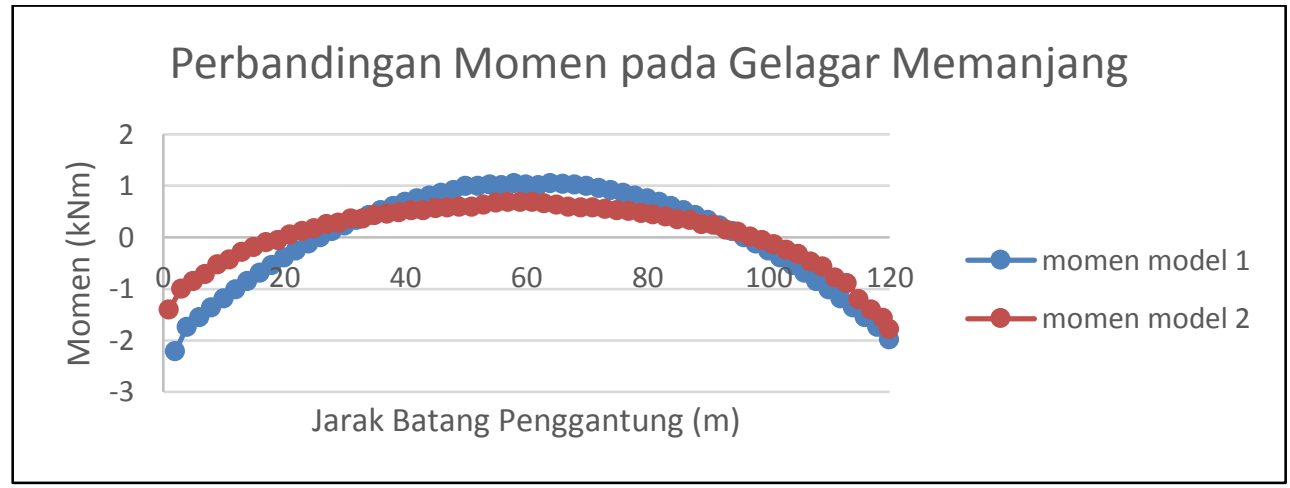

Gambar 12. Perbandingan nilai momen pada gelagar memanjang Model 1 dan Model 2

Berdasarkan grafik pada Gambar 12 momen pada Model 1 lebih besar dibandingkan Model 2 hal ini terjadi karena model satu memiliki lebih banyak kabel yang menambah berat sendiri pada struktur seperti terlihat pada Gambar 13.

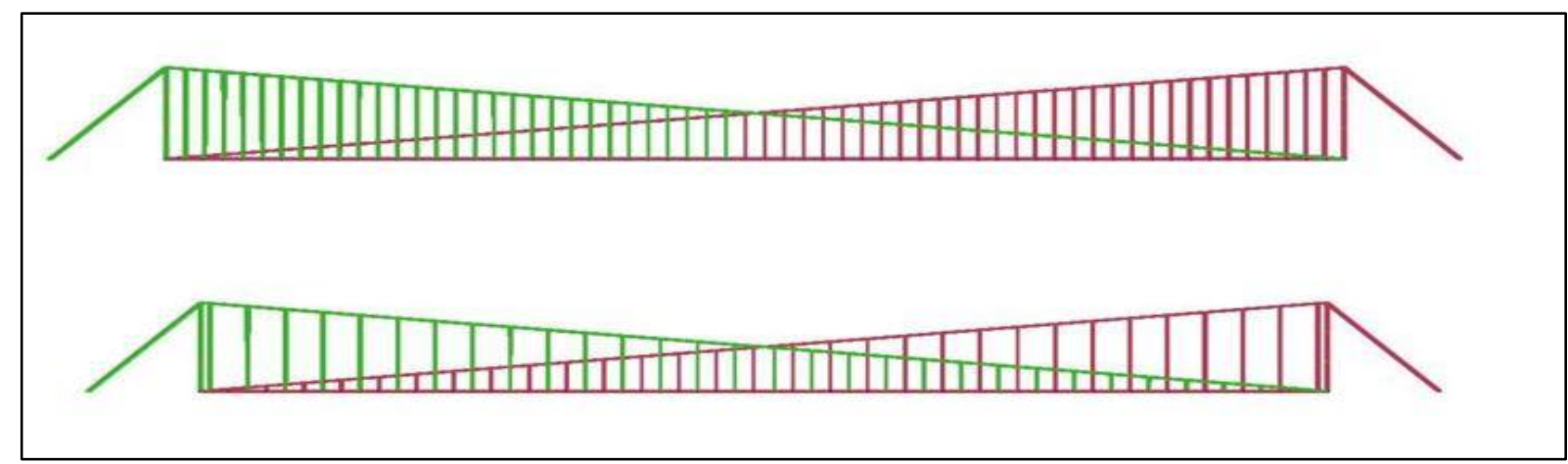

Gambar 13. Perbandingan geometri jembatan Model 1 dan Model 2

Nilai lendutan pada Model 1 tidak memenuhi batas yang disyaratkan pada Tabel 1 perbandingan nilai lendutan pada Model 1 dan Model 2 pada kombinasi batas layan dapat dilihat pada Gambar 14. 


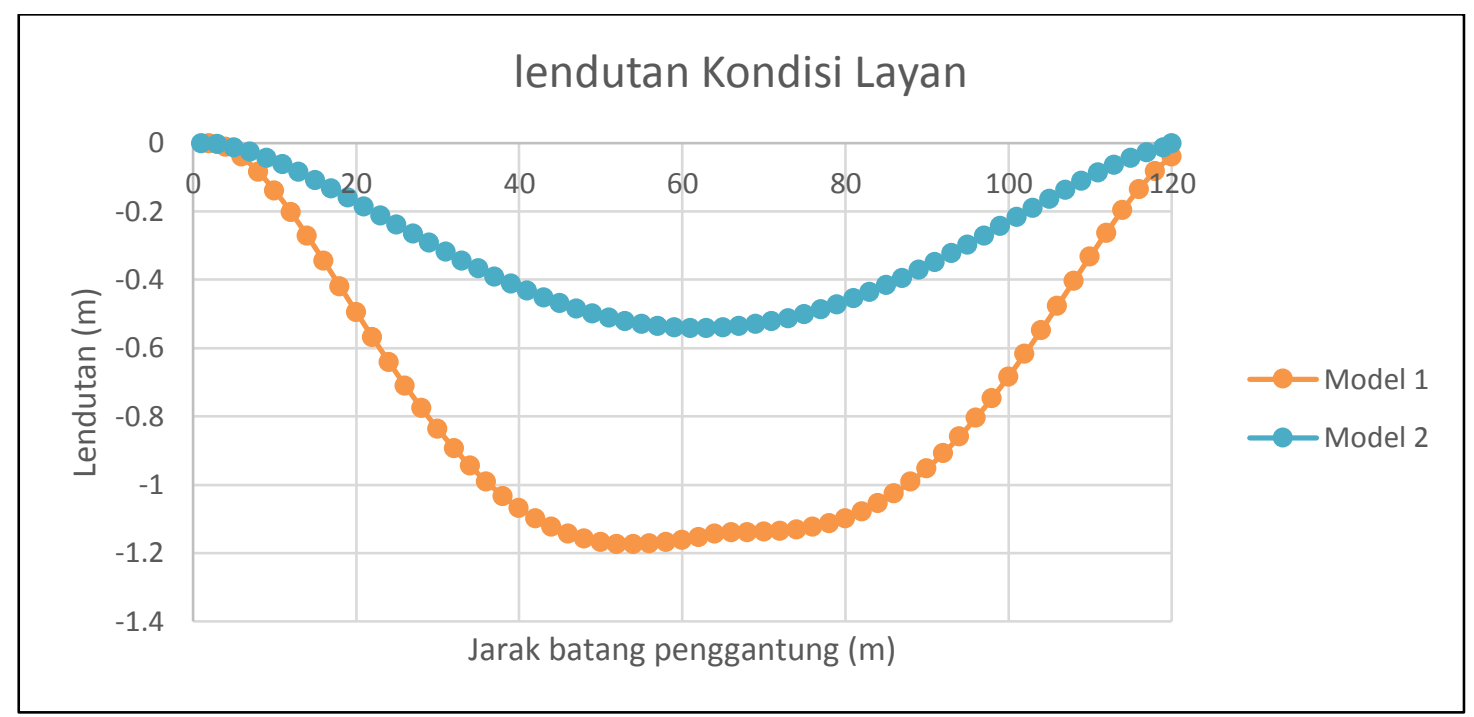

Gambar 14. Perbandingan lendutan akibat kombinasi beban layan pada Model 1 dan Model 2

Lendutan yang terjadi pada Model 1 dan Model 2 memberikan selisih nilai yang besar yaitu $63,24 \mathrm{~cm}$ atau $53,86 \%$ dari nilai lendutan Model 1 . Selain nilai selisih lendutan yang besar nilai lendutan pada Model 1 dan Model 2 tidak berasa pada titik yang sama.

\section{SIMPULAN}

Hasil dari studi evaluasi jembatan asimetris ganda dengan 2 konfigurasi model yang berbeda dapat disimpulkan bahwa:

1. Konfigurasi Model 1 dan Model 2 memliki kekuatan struktur yang cukup untuk menahan beban-beban yang direncanakan.

2. Dimensi yang digunakan pada konfigurasi 1 dan 2 sama membuat konfigurasi 2 menunjukan kekuatan struktur yang lebih baik.

3. Pada konfigurasi 2 dengan dimensi yang sesuai dengan kebutuhan maka kinerja struktur akan sama dan lebih ekonomis.

\section{UCAPAN TERIMA KASIH}

Ucapan terima kasih penulis sampaikan kepada pembimbing yang telah membimbing serta kepada Puslitbang Jalan Jembatan Bandung yang telah membimbing serta membantu penulis dalam penelitian ini.

\section{DAFTAR RUJUKAN}

Dewobroto, W. (2005). Perkembangan Jembatan di Indonesia. Karawaci: Universitas Pelita Harapan.

Isyana, A., \& Herbudiman, B. (2008). Studi Parameter Desain Dimensi Elemen Struktur Jembatan Gantung Pejalan Kaki Dengan Bentang 120m. Bandung: Itenas.

Steel Wire Rope, Ltd. (2018, Maret 5). www.stee/wwirerope.com. Dipetik Maret 5, 2018, dari www.steelwwirerope.com:

http://www.steelwwirerope.com/Datasheet-6x36Galvanised-WS-IWRC

Sukmara, G. \& Nugraha, W. (2016). Jembatan Gantung Asimetris untuk Pedesaan (JUDESA). Seminar Hasil Litbang, Pusat Penelitian dan Pengembangan Jalan dan Jembatan. hal. 1-6. Bandung: Kementerian PUPR.

Supriyadi, B., \& Muntohar, A. (2007). Jembatan. Yogyakarta: Beta Offset. 
Surat Edaran Menteri Pekerjaan Umum No. 02/SE/M/2010 . (2010). Pemberlakuan Pedoman Perencanaan dan Pelaksanaan Konstruksi Jembatan Gantung Untuk Pejalan Kaki. Jakarta: Kementrian Pekerjaan Umum. 